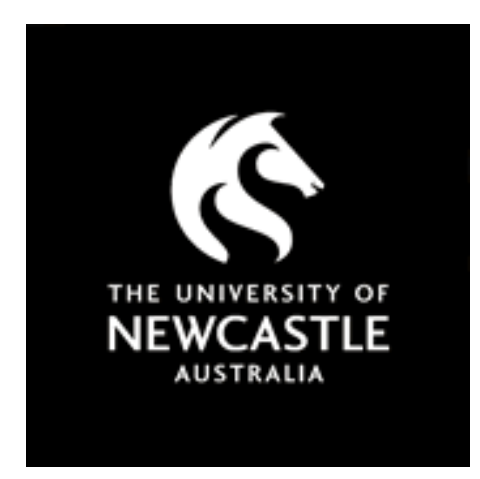

NOVA

University of Newcastle Research Online

nova.newcastle.edu.au

Gore, Jennifer; Barron, Rosie Joy; Holmes, Kathryn; Smith, Maxwell. "Who says we are not attracting the best and brightest? Teacher selection and the aspirations of Australian school students", Published in The Australian Educational Researcher Vol. 43, Issue 5, p. 527-549. (2016)

Available from: http://dx.doi.org/10.1007/s13384-016-0221

The final publication is available at Springer via http://dx.doi.org/10.1007/s13384-016-0221$\underline{8}$.

Accessed from: http://hdl.handle.net/1959.13/1338178 


\title{
Who says we're not attracting the best and brightest? Teacher selection and the aspirations of Australian school students
}

\author{
Jennifer Gore $^{1 *}$, Rosie Joy Barron ${ }^{1}$, Kathryn Holmes ${ }^{2}$, Maxwell Smith ${ }^{1}$ \\ ${ }^{1}$ School of Education, University of Newcastle, Australia \\ ${ }^{2}$ School of Education, Western Sydney University, Australia
}

\section{Acknowledgements}

The data for this analysis came from a linkage project funded by the Australian Research Council and the New South Wales Department of Education under grant LP12100013. The study reported in this paper was funded by the Commonwealth's Higher Education Participation Programme under the National Priorities Pool scheme, and supported by the Teachers and Teaching Research Centre and Centre of Excellence for Equity in Higher Education at the University of Newcastle, Australia. The authors wish to acknowledge the support provided in the preparation of this manuscript by Dr Leanne Fray, Dr Natasha Weaver, Claire Wallington, and Le Hoang Le. We also value the input of anonymous reviewers. We are most grateful to the students and their parents, carers, and teachers for their participation in this project.

\footnotetext{
* Corresponding author at: The University of Newcastle, School of Education, University Drive, Callaghan NSW 2308, Australia. Tel.: +61 24921 6709. Email address: jenny.gore@ newcastle.edu.au 


\title{
Who says we're not attracting the best and brightest? Teacher selection and the aspirations of Australian school students
}

\begin{abstract}
Internationally, the quality of teachers is a growing focus of educational reform, with new policies attempting to ensure that only the 'best and brightest' are selected for the teaching profession. This article tests the assumption underpinning these developments that prospective teachers lack the desired academic and personal qualities. Drawing on data on the career aspirations of 6,492 Australian school students in Years 3 to 12, we investigated who, among these students, expressed interest in teaching and their reasons for doing so. Using logistic regression, we found that interest in teaching was widespread and prior academic achievement was not a significant predictor. Thematic analysis of reasons expressed for interest in teaching indicated that working with children and/or in specific subject areas, altruism, and perceptions of personal suitability for the job dominated student responses. These data provide a counter-narrative to the primacy, in policies for teacher recruitment and selection, of needing to attract 'better' students. We argue that policies for improving teacher quality should also capitalise on the widespread interest in teaching among school students. Without such a discursive broadening, we caution that current attempts to attract the 'best and brightest' risk undermining the very goals espoused.
\end{abstract}

\section{Keywords}

Aspirations; motivations; teacher selection

\section{Introduction}

Policies to regulate who enters teacher education programs have gathered momentum in recent times, particularly in the context of international comparisons of student performance. As nations look to shore up their relative standing and meet government and public expectations, accountability for student outcomes invariably turns to the quality of teachers and quality of those who enter teacher education programs. Comparisons with education systems in nations that perform well on PISA, such as Finland and South Korea for example, mean that the preparation and academic qualifications of teachers come under particular scrutiny (Barber and Mourshed 2007). If Finland requires that all teachers have a master's degree (Sahlberg 2007) and South Korea only accepts applicants from the top 5\% of the high school academic cohort (Auguste et al. 2010), then Australia needs to lift its requirements for entry to teaching, so the logic goes.

Heightened attention internationally to the 'quality' of teachers has focused firmly on the academic achievement of entrants to and graduates of teacher education programs (Auguste et al. 2010; Hobson et al. 2010). Federal and state departments of education in Australia, for example, have implemented policy measures to ensure that all teachers are within the 'top 30\%' of the population in literacy and numeracy achievement (Australian Government Department of Education and Training 2015; NSW Board of Studies Teaching and Educational Standards [NSW BOSTES] 2015a). This 'teacher selection' activity is 
presented as critical to producing better outcomes for students and raising the esteem of the teaching profession (Teacher Education Ministerial Advisory Group [TEMAG] 2014). While these are worthy goals, current regulations to ensure better 'quality' entrants to teacher education raise complex and unresolved questions of how quality is to be determined and what unintended effects might result from this tightening regulation of who can teach.

In this paper, we consider the basis for current teacher selection discourses and explore their potential to undermine the very goals espoused. We outline how, in policy and mainstream media, the dominant narrative is that current and prospective teachers fail to make the 'quality' grade which, in turn, contributes to an image problem that deters 'the best and the brightest' from seeking careers in teaching. We test the basis for this narrative, and associated policy, by analysing data on those who, among a large sample of school students, aspire to become teachers. That is, we respond to concerns about who should teach by asking who wants to teach and why, thus illuminating perspectives that have largely been absent from dominant representations of teachers and would-be teachers. Our data provide a valuable 'counter-narrative' (Ulmer 2016) demonstrating a need for more careful consideration of the discursive and material effects of current regulatory policy.

\section{The best and the brightest}

In 2011, the Australian Institute for Teaching and School Leadership (AITSL) introduced a national set of standards and procedures for the accreditation of initial teacher education (ITE) programs, declaring that 'it is expected that applicants' levels of personal literacy and numeracy should be broadly equivalent to those of the top 30 per cent of the population' (AITSL 2011, p. 12). The document also decreed that providers that accept students into ITE programs who do not meet this requirement 'must establish satisfactory additional arrangements to ensure that all students are supported to achieve the required standard before graduation' (AITSL 2011, p. 12).

Since announcement of this national standard for all teacher education programs, universities, teacher registration authorities, and AITSL, among others, have wrestled with how it is to be interpreted and implemented. For instance, questions have been raised about: (1) how such performance is to be identified in states and territories where senior secondary attainment is not expressed in percentages; (2) the degree to which students should exceed the minimum entry requirements; and, (3) how this ought to be evaluated (University of New England n.d.). AITSL's (2012) own guide to the accreditation process, released the following year, stated that work had been commissioned to better define the levels of personal literacy and numeracy that would meet this requirement. Throughout this period, concerns about apparent deficiencies in the quality of teachers, teacher education, and Australian education more broadly gained particular momentum in public and professional discourse. The press to ensure that teaching attracts the best and the brightest has constructed a powerful narrative of teachers and teacher education as not good enough, manifest in countless reviews of teacher education (Louden 2008).

This narrative has been particularly virulent in the news media whereby universities have been accused, with some basis in fact, of setting poor academic standards for entry into teaching degrees (e.g., Byrne 2013; Ferrari 2015; McDougall 2014; Wilson et al. 2015) and using teaching to make up shortfalls in enrolments, regardless of the academic achievement levels of applicants (Dinham 2013). Low academic standards are seen as making teaching a less attractive pathway for 'high quality' applicants (Dinham et al. 2008). The extended logic 
is that declining 'attractiveness' combined with projected workforce shortages will only exacerbate this problem. Hence, addressing the problem of teacher quality is framed not only as a matter of keeping those deemed 'inappropriate' out but also finding ways to bring those with the desired credentials in. To this end, Preston (as cited in Ingvarson et al. 2014) suggests raising the status of teaching, improving program rigour, and raising entry standards as three key considerations, concluding that 'of greatest substantive importance [in attracting better applicants], high entry standards requiring successful completion of a rigorous and effective initial teacher education program, indicate that teachers will have highly capable, professional colleagues with whom they will work' (p. 67).

While entry standards is the primary focus, the former Federal Minister for Education, Christopher Pyne (2014), portrayed teacher education programs as 'too theoretical', making for graduates who cannot teach effectively in key areas, especially literacy and numeracy. According to the Teacher Education Ministerial Advisory Group (TEMAG 2014), teachers are graduating without the requisite knowledge and skills to be 'classroom ready', and this shortfall in quality must be addressed in order to lift student outcomes and arrest a decline in the performance of Australian students in international comparative testing. More broadly, TEMAG declared a lack of public confidence that those entering teaching possess the 'academic skills and personal qualities that engage students and foster learning' (p. 8).

In response, and with federal government directive, the Australian Institute for Teaching and School Leadership (AITSL) has issued requirements for initial teacher education providers to 'apply selection criteria for all entrants, which incorporate both academic and non-academic components that are consistent with engagement with a rigorous higher education program' (AITSL 2015, p. 12). Providers are also required to publish a rationale for their selection approach, as well as any exemptions made. Some states and territories have developed their own mechanisms for achieving the necessary academic standards. For example, NSW authorities have restricted school leaver entry into teaching degrees to those who graduate with three Band 5s in their Higher School Certificate (HSC) ${ }^{1}$, including English (NSW BOSTES 2015a), and, according to accounts in news media, will soon introduce mandatory 'personality assessments' to 'weed out candidates unsuited to teaching before they begin their degrees' (Bagshaw 2016, n.p.). By 2020, the South Australian state government seeks to establish a requirement for all new teachers to hold a master's qualification (Trounson 2016). AITSL's federal reforms also affect those already enrolled in teaching degrees through the introduction of mandatory testing in literacy and numeracy, which has to be successfully completed in order to gain registration as a teacher upon graduation (Australian Government Department of Education and Training 2015). These moves fortify the 'best and brightest' discourse, touching on both the academic and non-academic qualities of those who seek to teach.

\footnotetext{
${ }^{1}$ As stated on the NSW BOSTES (2015b) website, 'student performance in each HSC course is measured against defined standards. HSC marks for each course are divided into bands and each band aligns with a description of a typical performance by a student within that mark range. The performance bands and descriptions give meaning to the HSC mark. For a 2 unit course, Band 6 indicates the highest level of performance' (n.p.). A Band 5 result includes marks ranging from 80 to 89 out of 100 (NSW BOSTES 2015b).
} 


\section{Does the 'best and brightest' discourse attract or deter?}

While the objective of these reforms is to 'raise standards' in teacher education so as to lift public perceptions of the teaching profession, the main casualties of such a public campaign are liable to be current and would-be teachers. Some scholars have called upon teachers and educational researchers to stake a greater claim in such public debates in order to provide a counter-narrative to increasingly derogatory representations of teachers (e.g., Allard et al. 2014; Goldstein 2011b; Ulmer 2016) and a number of Australian researchers have taken up this challenge. For instance, Ure (2015) questions the legitimacy of a 'crisis' in teacher quality, and Graham (2015) points out that claims of widespread ineptitude amongst preservice and early career teachers lacks a clear evidence base.

As Davison suggests, current regulations could be 'putting off people [who] do have a very strong interest in teaching' (as cited in McNeilage 2014, n.p.). For Ure (2015), deterring prospective teachers will exacerbate current workforce shortages in certain academic and/or geographical areas of need. Indeed, concerns about the quality of teachers might be unsustainable in the context of projected increasing workforce demand for teachers (Weldon 2015) and/or the long-term consequences of smaller cohorts arising as a result of the current emphasis on 'exclusivity' and 'mediocrity'.

Much of the discourse on the poor quality of teachers rests on a thin evidence base. This has been particularly so in relation to current concerns about the admission of high school leavers into teaching with poor academic credentials. The most prominent measure used by tertiary education providers to allocate places for entry into programs of study is the Australian Tertiary Admission Ranking (ATAR), expressed as a numeric value that represents students' ranking relative to their national cohort upon completion of secondary schooling. While ATAR 'cut-offs' for entry to teaching degrees have in fact declined in recent years (Dinham 2013), these concerns often fail to account for: the small percentage of students coming into teaching with an ATAR (less than 20\%); the inadequacy of ATAR as a predictor of student performance at university; ATAR as a norm-referenced rather than criterion-referenced indicator of relative performance (meaning that no matter how high performances are, there will always be a top $10 \%$ or bottom $50 \%$, etc.); and, ATAR cut-offs as an indication of supply and demand, rather than quality (Devlin 2016). Figure 1, for example, shows that enrolments in teacher education in 2014 were $42 \%$ greater than 2001 enrolments $^{2}$. Moreover, average yearly increase in enrolments for the period 2002-2009 was $1.9 \%$ but for 2010-2014 it was 4.1\%. During this latter period there was an intensified national push to widen participation in higher education, including for people from low socioeconomic status backgrounds (Bradley et al. 2008), many of whom make their foray into higher education through teaching, nursing, and the arts (Southgate et al. 2014). In this context and with an increasing number of places available, simplistic accounts of declining ATAR 'cut-offs' tell a fraction of a much more complicated story. In terms of our argument, while ATAR 'cut-off' data indicate that academic requirements for entry are falling, there is no evidence that the quality of students in the top $30 \%$, for example, is changing from year to year. Arguably, ATAR has been mis-used to strengthen critiques of the quality of entrants to teacher education and teachers in general.

\footnotetext{
${ }^{2}$ Figure 1 was created using data that is publically available via $u C u b e$ (Australian Government Department of Education and Training 2016) under the Creative Commons Attribution 3.0 Australia Licence.
} 


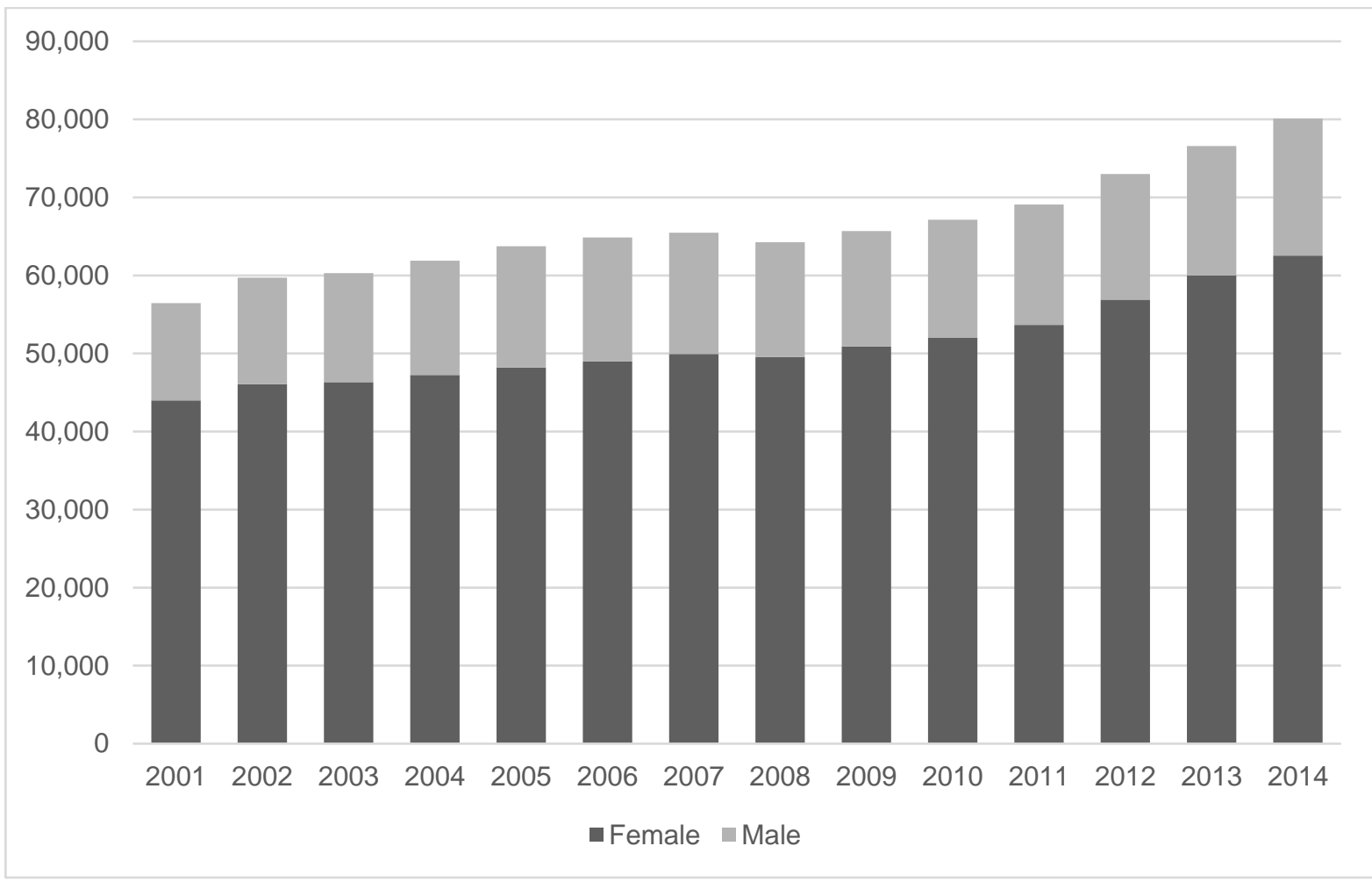

Fig. 1 Continuing and commencing students (both domestic and overseas) enrolled in undergraduate 'Education' programs in Australia, 2001-2014

Nonetheless, nuanced understandings of entry to teaching appear to have limited purchase in interrupting the increasingly dominant narrative that teaching degrees are populated by underqualified or inappropriate candidates and that this must be addressed through attempts to attract and retain the 'best and brightest' to the teaching profession. Just as the ATAR narrative is over-simplified in public and policy discourse, so too is the poor quality entrant narrative, in light of our data on who, among school students, expresses interest in teaching. Our study provides new insight on the degree to which teaching is already attracting suitable candidates.

\section{The study}

For this analysis, we drew on data from the mixed method Aspirations Longitudinal Study (Gore et al. 2015) focusing on the career aspirations of students in Years 3 to 12. In a survey administered annually from 2012 to 2015 , nearly 6,500 participating students were asked to indicate their occupational interests and give reasons for their choices. Prior studies of aspirations for teaching are based, overwhelmingly, on the views of adult respondents. Indeed, we could find only six studies - published in English, in the period from 2005 to 2015 (Gore et al. 2016) - where interest in teaching as a first career among school-aged students was reported (Cross and Ndofirepi 2015; Flores and Niklasson 2014; Lai et al. 2005; Lovett 2007; Manuel and Hughes 2006; Yüce et al. 2013). Our data on the aspirations of primary and secondary school students who are considering teaching thus contributes to this body of research and provides a unique perspective from which to consider both the need for 
and the effects of current policies. Are substantial numbers of bright students interested in teaching? Are they among the 'best,' with the 'right' kinds of motivations?

Recent research has demonstrated that children are forming career interests at an early stage of their schooling (Gore et al. 2016) and that most young children have aspirations for, and can envisage, future careers (Moulton et al. 2015). A widely-recognised process of circumscription and compromise (Gottfredson 1996) has been used to explain changes in career aspirations as children grow. The aspirations for teaching among young children were thus seen as providing an important foundation for considering how school year level might account for different levels of interest.

The students who participated in the study were in Years 3, 5, 7, or 9 at 64 government schools in New South Wales, Australia, when the study commenced in 2012 and in Years 6, 8, 10, and 12, respectively, in the final year, 2015. A total of 6,492 students completed the survey in one or more years, yielding a total of 10,543 valid surveys. Of the participating students, 5,925 nominated at least one occupation in any survey. Our focus in this paper is on the 821 students who, in one or more of the surveys, expressed an interest in teaching. Investigating which kinds of students named teaching, and why, using a range of student background and school-related variables, provides insight into questions about the academic credentials and dispositions toward teaching of students who aspire to teach. While careful not to provide an overly celebratory account, we acknowledge cause for cautious optimism about the future of teaching which, we argue, provides critical input into current debates that touch not only the work, but the very character, of teachers.

\section{Methods}

To describe the sample of students who expressed interest in teaching, a range of variables was used. Where possible, student characteristics were obtained from the information recorded on students' school enrolment forms, as provided by the NSW Department of Education. Gender was categorised as male or female. Aboriginal and Torres Strait Islander status was categorised as Indigenous or non-Indigenous. Geographical location was determined by school postcode and dichotomised as metropolitan or provincial. Language background was categorised as English-speaking background or language background other than English (LBOTE). The cross-sectional and longitudinal effects of age were measured by survey year and cohort variables, respectively. SES was determined by combining parental level of education and parental occupation and was categorised into quartiles using state-wide data (see Gore et al. 2015 for details). A categorical measure of cultural capital (Bourdieu 1986) was also created from a combination of survey items about frequency of participation in various cultural activities.

A number of school-related variables were also considered. The Index of Community Socio-Educational Advantage (ICSEA), created by the Australian Curriculum, Assessment and Reporting Authority (ACARA), provides a standardised scale measuring school advantage based on summarising student-level data. A higher score indicates the relative advantage of a school. This measure was developed in order to compare aggregate achievement results between schools using scores from the National Assessment Program Literacy and Numeracy (NAPLAN) standardised tests of academic achievement. ICSEA and NAPLAN scores were categorised for the analysis using cut-offs from the state quartile values in each year. Perceived achievement relative to peers was a self-assessment variable based on the question 'How are your marks this year compared with other students?' with the 
response options of 'Well below average, Below average, Average, Above Average, or Well above average'. Finally, a variable was constructed based on whether or not students reported participating in any tutoring, categorised as 'yes' or 'no'.

This combination of student-related and school-related predictor variables was selected to ensure broad consideration of factors previously associated with interest in teaching as a career. There is a long history of differential participation in teaching by gender (especially in fields of Early Childhood and Primary education) (Commonwealth Department of Education 2014; Weldon 2015) and teaching has been an important pathway for Aboriginal students and those from low SES backgrounds entering higher education (James et al. 2008; Southgate et al. 2014). We were also interested in the differential predictive power of other student demographic variables (including age, LBOTE, location, and parent in a teaching occupation). Cultural capital was of interest because of its strong association with matters of status and teaching's relatively low occupational status in Australia (Dinham 2008). Variables associated with being in school (school ICSEA, relative perception of academic performance, prior achievement, and tutoring) were tested in order to consider, in a preliminary way, the extent to which being at school or certain types of schools might mediate students' interest in a teaching career. The relative effects of these variables were tested through logistic regression analysis, described below.

The primary outcome for the quantitative analysis was a binary variable indicating whether or not a student nominated teaching in the given survey year. Students were asked in the survey if they knew what kind of work they wanted to do: 'What would you like to do when you grow up?' (primary students); 'Do you know what kind of work you would like to be doing at 25 years of age?' (secondary students). If they answered 'yes', they were then asked to name the kind of work (in an open-ended question) and their reasons for choosing it. If they answered 'no', they were asked for some of the kinds of work or specific jobs they had thought about doing (if any) and could nominate up to three occupations ('Do you have any thoughts about possible future work or jobs? What are the names of the jobs you have thought about?') and provide reasons for their interest. These nominated careers were coded using the Australian and New Zealand Standard Classification of Occupations (ANZSCO) scheme developed by the government statistical agencies of Australia and New Zealand for use in censuses and workforce surveys. The three-digit category (241) "School Teachers" used for this analysis includes the four-digit categories 'Early Childhood (Pre-primary School) Teachers' (2411), 'Primary School Teachers' (2412), 'Middle School Teachers' (2413), 'Secondary School Teachers' (2414), and 'Special Education Teachers' (2415), but not private tutors such as music and dance teachers working outside of schools. Of the 821 students who nominated school teaching, 430 did not specify a particular type of teaching at the four-digit level.

Logistic regression models were used to determine if there were differences in the characteristics of students who expressed interest in teaching and those who did not. The logistic regression models were fitted within a Generalized Estimating Equation (GEE) framework, a method robust against violations of normality and missing data assumptions, to adjust for the correlation of outcomes within students due to repeated measures ${ }^{3}$. The models were also adjusted to account for the nesting of students within schools. The GEE model was compared to an equivalent random effects Generalized Linear Mixed Model employing the

\footnotetext{
${ }^{3}$ A Generalized Estimating Equation (GEE) takes into account that students who completed the survey were in different grades and some students completed the survey on multiple occasions.
} 
same data and variables (Goldstein 2011b; Zhang et al. 2012), both of which produced similar estimates and $p$-values. A series of univariate logistic regressions was undertaken for each of the occupation outcomes, reported as odds ratios and associated $p$-values (Table 1). Data for categorical variables are presented as numbers of students and proportions (as row percentages) within groups. All student-related characteristics were then included in a regression model as potential predictors of interest in teaching. A second regression model included the school-related variables. The same variables were significant in Models 1 and 2, and hence only Model 2 is reported, as adjusted odds ratios and adjusted $p$-values (see Table 1). Data were analysed using SAS software version 9.4. Statistical significance was set at 0.05 .

The qualitative data, in the form of textual responses to the survey question 'Why do you want to do this work?' were read by at least two members of the research team and individually coded using NVivo software. This process entailed the categorisation of responses which were subsequently collapsed into 24 themes. Themes were discussed, built upon, and revised by the researchers throughout the process. The analysis of these data was designed to address recent calls to go beyond a simple focus on "the brightest" as identified by academic achievement. Increasingly, teacher selection processes are demanding assessment of a broader range of 'non-academic' criteria in order to ensure that the "best" people go into teaching. We use these data to provide insight into the qualities (or motivations) of those who aspire to teach.

\section{Results}

\section{Widespread interest in teaching}

Of all students who named a specific career interest, 13.9\% named teaching, comprised of 821 of the 5,925 students who named at least one occupation in any survey. Considering all survey responses $(N=10,543)$ in which a specific occupation was named, teaching accounted for $9.8 \%$ of all named jobs ( $n=1,029$ responses). Teaching was second in popularity only to careers in sports, and was ahead of other frequently named occupations such as: veterinarian; actor, dancer, and other entertainer; animal attendant and trainer; police; defence force; music professional; life scientist; and, engineering professional.

The degree to which this high level of interest in teaching was distributed across student groups or concentrated among particular types of students was informed by the results of the regression analysis. Significant effects ${ }^{4}$ for the choice of teaching were found for three variables only - gender, Indigenous status, and age cohort - thus signalling widely distributed interest across all other variables examined. That is, no significant effects were found for SES, cultural capital, language background, school location, having a parent who is a teacher, school ICSEA, prior achievement, self-perception of relative academic performance, or participation in tutoring.

The significant effects for gender, Indigenous status, and cohort indicate areas of concentrated interest in teaching. Specifically, the odds of girls naming teaching were nearly

\footnotetext{
${ }^{4}$ Differences between Models 1 and 2 would have indicated a mediating effect for the school-related variables of ICSEA, NAPLAN results, self-rated relative performance, and tutoring, but results across the two models were highly consistent. This was not the case for some other occupations that we examined within the larger study (see Gore et al. 2016).
} 
five times the odds of boys naming teaching $(O R=4.74, p<0.001)$. Indigenous students were more likely to express interest in teaching than non-Indigenous students $(O R=1.44, p=$ 0.015). Students in the 'middle years' cohort (moving from Year 5 to Year 8 during the study) were less likely to express interest in teaching than students in the younger and older groups $(O R=0.74, p=0.015)$ (see Figure 2). Despite this significant cohort effect, interest in teaching across the age groups was consistently high, between 8 and $13 \%$ of all survey responses for the four age cohorts.

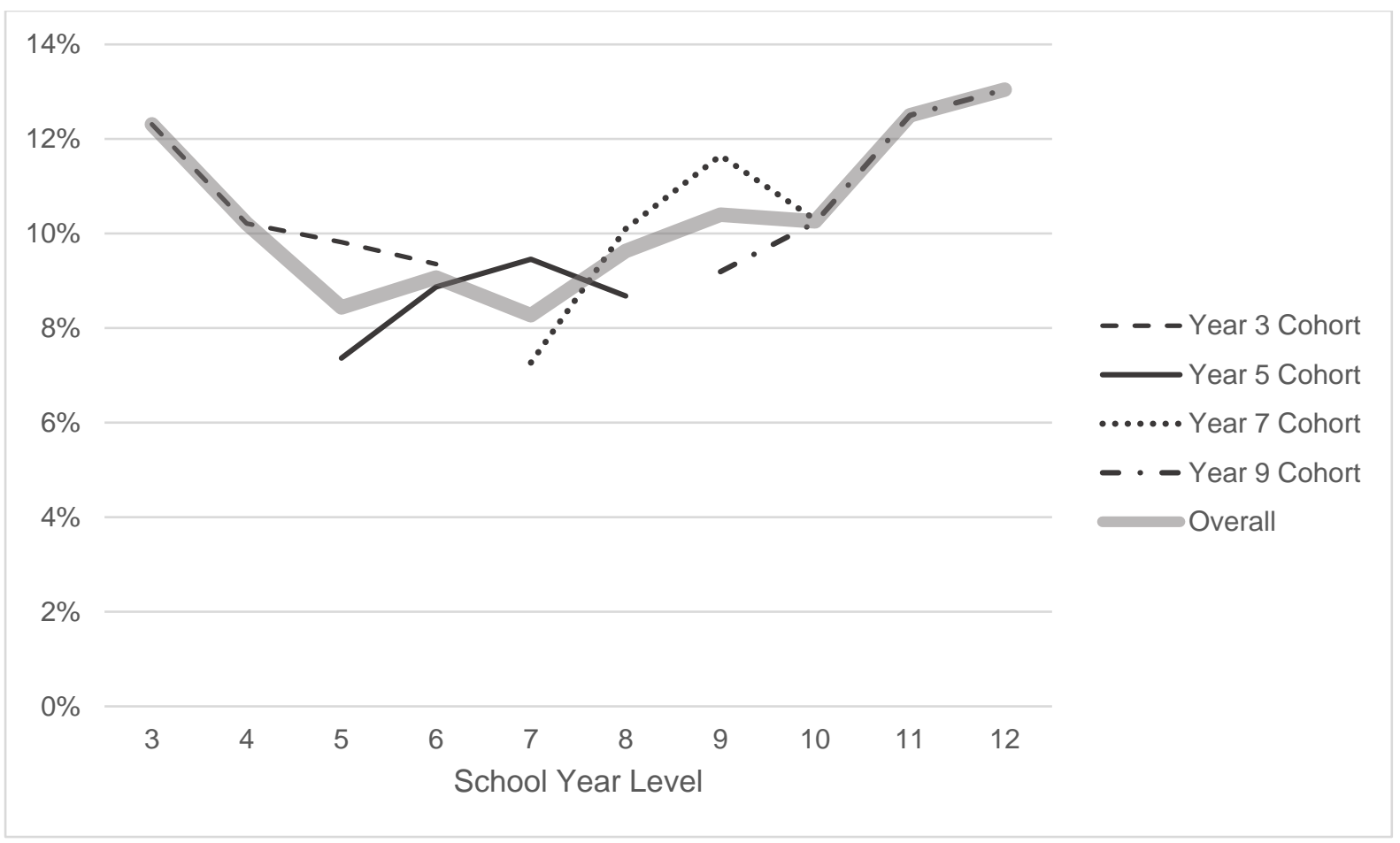

Fig. 2 Interest in teaching by student cohort

\section{Bright students are interested in teaching}

Of particular note in the current policy context, prior achievement was not a significant predictor of interest in teaching, with students in the top quartile - the 'brightest'? - being no less or more likely to name teaching as a career interest than students in the lower three quartiles. Indeed, there was slightly more interest among students in the top two NAPLAN quartiles (quartile 3,11\%; quartile 4,10\%) compared with students in the lower quartiles (quartile 1,8\%; quartile 2, 9\%). Moreover, when considering the NAPLAN quartiles from which students expressed interest in teaching, 255 of the 821 students who named teaching, or $31 \%$ of this sample, came from the top quartile. Similarly self-rated relative academic performance was not statistically significant in the regression analysis, although higher proportions of students who were interested in teaching considered themselves 'average', 'above average', or 'well above average' (9-11\% for these categories) than was the case for students who rated their own performance as 'below' or 'well below' average (6\%). In looking only at the students who named teaching, 52.4\% rated themselves as 'above' (39.5\%) or 'well above' (12.9\%) average. 


\section{Not a back-up plan}

Given the widespread interest in teaching among students in our sample, a multinomial regression analysis was conducted (multinomial GEE) comparing three groups of survey responses - surveys in which a student expressed interest in teaching only (that is, teaching but no other occupations) $(n=501)$; those in which a student expressed interest in teaching among other occupations $(n=528)$; and those in which a student expressed interest in other jobs (not teaching) ( $n=8,305)$ (Table 2). This analysis was designed to test the possibility that large numbers of students were naming teaching as a secondary or 'back-up' choice and that such students might have different characteristics from those who expressed singular interest in teaching. The analysis showed that the characteristics of students interested in teaching only and those interested in teaching among other jobs varied little in terms of proportions, with the one exception being that Indigenous students named teaching only $(8.5 \%)$ in higher numbers than those who named teaching in conjunction with other jobs $(5.8 \%)$.

We also compared the proportion of survey responses in which students named a singular interest in teaching (49\%) with the proportion of survey responses from our larger sample in which students expressed singular interest in other popular occupations (Arts professional 56\%, Nurse 54\%, Veterinarian 54\%, Architect 52\%, Engineer 52\%, Teaching 49\%, Law 49\%, Science 49\%, Medicine 47\%, Social/Welfare professional 47\%). We found that students who considered teaching were no more or less likely to name multiple occupational interests than students considering other occupations requiring a university degree, thus providing further evidence against a 'back-up plan' as an explanation for the high level of interest in teaching.

In summary, these data challenge the contemporary policy view that teaching is no longer attracting 'bright' or academically capable students. Indeed, 31\% of those interested in teaching were in the highest achievement quartile. More broadly, we found a high level of interest in teaching that is widespread among students across the range of demographic and educational variables that were investigated. The significance of these findings is discussed below, after we report findings from our analysis of the reasons given by students for their interest in teaching. 
$\underline{\text { Table } 1 \text { Teaching aspiration, student background factors, and school-related factors (Model 2) }}$

\begin{tabular}{|c|c|c|c|c|c|c|c|}
\hline \multirow[b]{3}{*}{ Characteristic } & \multicolumn{4}{|c|}{ Teaching career choice } & \multicolumn{3}{|c|}{ Model 2} \\
\hline & \multicolumn{2}{|c|}{ No } & \multicolumn{2}{|c|}{ Yes } & \multirow{2}{*}{$\begin{array}{r}\text { Adjusted } \\
p \text {-value }\end{array}$} & \multicolumn{2}{|c|}{ Adjusted } \\
\hline & $n$ & $(\%)$ & $n$ & $(\%)$ & & OR & $(95 \% \mathrm{CI})$ \\
\hline \multicolumn{8}{|c|}{ Aboriginal \&/or Torres } \\
\hline \multicolumn{8}{|c|}{ Strait Islander status } \\
\hline Non-Indigenous & 8,466 & $(90.5)$ & 884 & $(9.5)$ & - & & \\
\hline Indigenous & 577 & $(87.3)$ & 84 & $(12.7)$ & $0.031 *$ & 1.44 & $(1.03-2.00)$ \\
\hline \multicolumn{8}{|l|}{ Student cohort } \\
\hline Year 3 cohort & 2,623 & $(89.6)$ & 303 & $(10.4)$ & - & & \\
\hline Year 5 cohort & 2,657 & (91.4) & 251 & $(8.6)$ & $0.015^{*}$ & 0.74 & $(0.58-0.94)$ \\
\hline Year 7 cohort & 2,593 & $(90.3)$ & 279 & $(9.7)$ & 0.410 & 0.89 & $(0.68-1.17)$ \\
\hline Year 9 cohort & 1,575 & $(89.4)$ & 187 & $(10.6)$ & 0.771 & 0.96 & $(0.70-1.30)$ \\
\hline \multicolumn{8}{|l|}{ Cultural capital } \\
\hline Quartile 1 & 2,313 & $(92.7)$ & 182 & $(7.3)$ & - & & \\
\hline Quartile 2 & 2,221 & $(90.5)$ & 233 & $(9.5)$ & 0.679 & 1.05 & $(0.82-1.35)$ \\
\hline Quartile 3 & 2,288 & $(89.3)$ & 275 & $(10.7)$ & 0.670 & 0.95 & $(0.73-1.22)$ \\
\hline Quartile 4 & 2,169 & $(87.6)$ & 306 & $(12.4)$ & 0.734 & 0.95 & $(0.73-1.25)$ \\
\hline \multicolumn{8}{|l|}{ Language } \\
\hline Other & 997 & $(91.2)$ & 96 & $(8.8)$ & - & & \\
\hline English & 8,108 & $(90.2)$ & 880 & $(9.8)$ & 0.998 & 1.00 & $(0.73-1.37)$ \\
\hline \multicolumn{8}{|l|}{ School location } \\
\hline Metropolitan & 5,504 & $(90.7)$ & 566 & $(9.3)$ & - & & \\
\hline Provincial & 4,009 & $(89.6)$ & 463 & (10.4) & 0.546 & 0.94 & $(0.76-1.16)$ \\
\hline \multicolumn{8}{|l|}{ SES } \\
\hline Quartile 1 & 2,037 & $(90.9)$ & 204 & $(9.1)$ & - & & \\
\hline Quartile 2 & 2,381 & $(89.5)$ & 280 & $(10.5)$ & 0.256 & 1.15 & $(0.90-1.46)$ \\
\hline Quartile 3 & 2,021 & (89.7) & 232 & (10.3) & 0.510 & 1.09 & $(0.84-1.43)$ \\
\hline Quartile 4 & 2,268 & $(90.7)$ & 233 & $(9.3)$ & 0.829 & 1.03 & $(0.77-1.38)$ \\
\hline \multicolumn{8}{|l|}{ Sex } \\
\hline Male & 4,896 & $(96.2)$ & 191 & $(3.8)$ & - & & \\
\hline Female & 4,209 & $(84.3)$ & 785 & $(15.7)$ & $<.001 *$ & 4.89 & $(3.91-6.11)$ \\
\hline \multicolumn{8}{|l|}{$\begin{array}{l}\text { Parent in teaching } \\
\text { occupation }\end{array}$} \\
\hline No, or unknown & 9,183 & $(90.4)$ & 973 & $(9.6)$ & - & & \\
\hline Yes & 331 & $(85.5)$ & 56 & $(14.5)$ & 0.053 & 1.42 & $(1.00-2.01)$ \\
\hline \multicolumn{8}{|l|}{ Survey year } \\
\hline 2012 & 2,341 & $(91.0)$ & 231 & $(9.0)$ & - & & \\
\hline 2013 & 3,600 & $(90.1)$ & 396 & $(9.9)$ & 0.923 & 0.793 & $(0.84-1.26)$ \\
\hline 2014 & 1,708 & $(89.5)$ & 200 & $(10.5)$ & 0.643 & 0.605 & $(0.84-1.35)$ \\
\hline 2015 & 1,865 & $(90.2)$ & 202 & $(9.8)$ & 0.749 & 0.555 & $(0.85-1.37)$ \\
\hline \multicolumn{8}{|l|}{ ICSEA quartile } \\
\hline Quartile 1 & 2,320 & $(90.0)$ & 258 & $(10.0)$ & - & & \\
\hline Quartile 2 & 3,854 & $(90.1)$ & 425 & $(9.9)$ & 0.977 & 0.979 & $(0.79-1.28)$ \\
\hline Quartile 3 & 950 & $(87.7)$ & 133 & (12.3) & 0.305 & 0.309 & $(0.84-1.71)$ \\
\hline Quartile 4 & 2,390 & $(91.8)$ & 213 & $(8.2)$ & 0.091 & 0.083 & $(0.52-1.04)$ \\
\hline NAPLAN quartile & & & & & & & \\
\hline Quartile 1 & 1,819 & (91.6) & 167 & $(8.4)$ & - & & \\
\hline
\end{tabular}




$\begin{array}{llllllll}\text { Quartile 2 } & 2,240 & (90.4) & 238 & (9.6) & 0.455 & 0.470 & (0.69-1.19) \\ \text { Quartile 3 } & 2,395 & (89.4) & 284 & (10.6) & 0.542 & 0.757 & (0.79-1.37) \\ \text { Quartile 4 } & 2,437 & (90.1) & 269 & (9.9) & 0.199 & 0.200 & (0.90-1.68)\end{array}$

Self-rated ability

Well below average

$181 \quad(93.8)$

$12 \quad(6.2)$

Below average $\quad 565 \quad(93.5)$

Average

$3,512 \quad(89.3)$

$39 \quad(6.5)$

$422 \quad(10.7)$

$\begin{array}{lll}0.830 & 1.09 & (0.49-2.44)\end{array}$

Above average

$2,753 \quad(88.9)$

343 (11.1)

0.141

$1.71 \quad(0.84-3.51)$

Well above average

$1,145 \quad(91.1)$

112 (8.9)

0.131

$1.75 \quad(0.85-3.61)$

$0.347 \quad 1.44 \quad(0.68-3.05)$

Tutoring

$\begin{array}{lllll}\text { No } & 7,736 & (90.0) & 860 & (10.0)\end{array}$

Yes

$1,550-(90.3)$

$166 \quad(9.7)$

0.337

$1.12 \quad(0.89-1.39)$

Notes. $O R=$ odds ratio. $\mathrm{CI}=$ confidence interval. $*$ denotes statistical significance. 


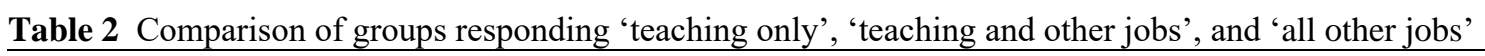

\begin{tabular}{|c|c|c|c|c|c|c|c|c|c|}
\hline \multirow[b]{3}{*}{ Characteristic } & \multicolumn{6}{|c|}{ Careers nominated } & \multicolumn{3}{|c|}{ Adjusted } \\
\hline & \multicolumn{2}{|c|}{$\begin{array}{l}\text { Teaching only } \\
(n=501)\end{array}$} & \multicolumn{2}{|c|}{$\begin{array}{l}\text { Teaching and } \\
\text { other jobs } \\
(n=528)\end{array}$} & \multicolumn{2}{|c|}{$\begin{array}{l}\text { All other jobs } \\
\quad(n=8,305)\end{array}$} & \multirow{2}{*}{$\begin{array}{r}p \text {-value } \\
\text { (GEE on } \\
\text { SRN) } \\
\end{array}$} & \multirow[b]{2}{*}{$O R$} & \multirow[b]{2}{*}{$(95 \% \mathrm{CI})$} \\
\hline & $n$ & $(\%)$ & $n$ & $(\%)$ & $n$ & $(\%)$ & & & \\
\hline \multicolumn{10}{|c|}{ Aboriginal \&/or Torres Strait } \\
\hline \multicolumn{10}{|c|}{ Islander status } \\
\hline Non-Indigenous & 420 & $(5.1)$ & 464 & $(5.6)$ & 7,407 & (89) & - & & \\
\hline Indigenous & 50 & $(8.5)$ & 34 & $(5.8)$ & 503 & (86) & 0.046 & 1.40 & $(1.01-1.96)$ \\
\hline \multicolumn{10}{|l|}{ Student cohort } \\
\hline Year 3 cohort & 176 & $(6.6)$ & 127 & $(4.8)$ & 2,353 & (89) & - & & \\
\hline Year 5 cohort & 109 & $(4.2)$ & 142 & $(5.5)$ & 2,335 & (90) & 0.008 & 0.72 & $(0.57-0.92)$ \\
\hline Year 7 cohort & 112 & $(4.5)$ & 167 & $(6.7)$ & 2,218 & (89) & 0.334 & 0.87 & $(0.66-1.15)$ \\
\hline Year 9 cohort & 98 & $(6.4)$ & 89 & $(5.8)$ & 1,348 & (88) & 0.667 & 0.93 & $(0.68-1.27)$ \\
\hline \multicolumn{10}{|l|}{ Cultural capital } \\
\hline Quartile 1 & 94 & $(4.4)$ & 88 & $(4.2)$ & 1,936 & (91) & - & & \\
\hline Quartile 2 & 103 & $(4.7)$ & 130 & $(5.9)$ & 1,958 & (89) & 0.885 & 1.02 & $(0.79-1.31)$ \\
\hline Quartile 3 & 132 & $(5.6)$ & 143 & $(6.1)$ & 2,072 & (88) & 0.438 & 0.90 & $(0.70-1.17)$ \\
\hline Quartile 4 & 155 & $(6.7)$ & 151 & $(6.5)$ & 2,010 & (87) & 0.397 & 0.89 & $(0.68-1.17)$ \\
\hline \multicolumn{10}{|l|}{ Language } \\
\hline Other & 42 & $(4.5)$ & 54 & $(5.8)$ & 839 & $(90)$ & - & & \\
\hline English & 432 & $(5.4)$ & 448 & $(5.6)$ & 7,138 & (89) & 0.863 & 0.97 & $(0.71-1.33)$ \\
\hline \multicolumn{10}{|l|}{ School location } \\
\hline Metropolitan & 259 & $(4.8)$ & 307 & $(5.7)$ & 4,827 & (90) & - & & \\
\hline Provincial & 242 & $(6.1)$ & 221 & $(5.6)$ & 3,477 & (88) & 0.667 & 0.95 & $(0.77-1.18)$ \\
\hline \multicolumn{10}{|l|}{ SES } \\
\hline Quartile 1 & 101 & $(5.1)$ & 103 & $(5.2)$ & 1,765 & (90) & - & & \\
\hline Quartile 2 & 138 & $(5.9)$ & 142 & $(6.0)$ & 2,072 & (88) & 0.236 & 1.16 & $(0.91-1.48)$ \\
\hline Quartile 3 & 117 & $(5.8)$ & 115 & $(5.7)$ & 1,790 & (89) & 0.616 & 1.07 & $(0.82-1.40)$ \\
\hline Quartile 4 & 98 & $(4.4)$ & 135 & $(6.0)$ & 2,017 & (90) & 0.941 & 1.01 & $(0.75-1.35)$ \\
\hline
\end{tabular}




\begin{tabular}{|c|c|c|c|c|c|c|c|c|c|}
\hline \multicolumn{10}{|l|}{ Sex } \\
\hline Male & 81 & $(1.8)$ & 110 & $(2.5)$ & 4,207 & (96) & - & & \\
\hline Female & 393 & $(8.6)$ & 392 & $(8.6)$ & 3,770 & (83) & $<.001$ & 4.85 & $(3.88-6.07)$ \\
\hline \multicolumn{10}{|c|}{ Parent in teaching occupation } \\
\hline No, or unknown & 470 & $(5.2)$ & 503 & $(5.6)$ & 8,001 & (89) & - & & \\
\hline Yes & 31 & $(8.6)$ & 25 & $(6.9)$ & 304 & (84) & 0.063 & 1.41 & $(0.98-1.98)$ \\
\hline \multicolumn{10}{|l|}{ Survey year } \\
\hline 2012 & 115 & $(5.1)$ & 116 & $(5.1)$ & 2,031 & $(90)$ & - & & \\
\hline 2013 & 200 & $(5.7)$ & 196 & $(5.6)$ & 3,107 & (89) & 0.795 & 1.03 & $(0.84-1.26)$ \\
\hline 2014 & 85 & $(5.0)$ & 115 & $(6.7)$ & 1,517 & (88) & 0.848 & 1.02 & $(0.81-1.29)$ \\
\hline 2015 & 101 & $(5.5)$ & 101 & $(5.5)$ & 1,650 & (89) & 0.763 & 1.04 & $(0.82-1.32)$ \\
\hline \multicolumn{10}{|l|}{ ICSEA quartile } \\
\hline Quartile 1 & 144 & $(6.3)$ & 114 & $(5.0)$ & 2,016 & (89) & - & & \\
\hline Quartile 2 & 197 & $(5.2)$ & 228 & $(6.1)$ & 3,342 & (89) & 0.942 & 1.01 & $(0.79-1.28)$ \\
\hline Quartile 3 & 72 & $(7.2)$ & 61 & $(6.1)$ & 861 & (87) & 0.299 & 1.21 & $(0.85-1.72)$ \\
\hline Quartile 4 & 88 & $(3.8)$ & 125 & $(5.4)$ & 2,086 & (91) & 0.094 & 0.75 & $(0.53-1.05)$ \\
\hline \multicolumn{10}{|l|}{ NAPLAN quartile } \\
\hline Quartile 1 & 92 & $(5.4)$ & 74 & $(4.4)$ & 1,523 & (90) & - & & \\
\hline Quartile 2 & 106 & $(5.0)$ & 120 & $(5.7)$ & 1,877 & (89) & 0.477 & 0.90 & $(0.69-1.19)$ \\
\hline Quartile 3 & 126 & $(5.8)$ & 136 & $(6.2)$ & 1,918 & (88) & 0.806 & 1.03 & $(0.79-1.36)$ \\
\hline Quartile 4 & 122 & $(5.1)$ & 140 & $(5.9)$ & 2,128 & (89) & 0.149 & 1.26 & $(0.92-1.73)$ \\
\hline \multicolumn{10}{|l|}{ Self-rated ability } \\
\hline Well below average & 9 & $(5.8)$ & 3 & $(1.9)$ & 144 & $(92)$ & - & & \\
\hline Below average & 22 & $(4.3)$ & 17 & $(3.3)$ & 475 & (92) & 0.931 & 0.96 & $(0.43-2.17)$ \\
\hline Average & 205 & $(5.8)$ & 217 & $(6.1)$ & 3,121 & $(88)$ & 0.304 & 1.46 & $(0.71-3.02)$ \\
\hline Above average & 161 & $(5.6)$ & 182 & $(6.3)$ & 2,526 & (88) & 0.313 & 1.46 & $(0.70-3.03)$ \\
\hline Well above average & 60 & $(5.1)$ & 52 & $(4.5)$ & 1,055 & $(90)$ & 0.665 & 1.18 & $(0.55-2.53)$ \\
\hline \multicolumn{10}{|l|}{ Tutoring } \\
\hline No & 421 & $(5.4)$ & 439 & $(5.7)$ & 6,869 & (89) & - & & \\
\hline Yes & 78 & $(5.1)$ & 88 & $(5.7)$ & 1,368 & (89) & 0.381 & 1.10 & $(0.88-1.38)$ \\
\hline
\end{tabular}


The analysis of students' reasons for their interest in teaching was undertaken to shed light on the 'dispositions' of students attracted to the job. Twenty-four different themes were identified which accounted for 880 of the 1,029 reasons given. Figure 3 depicts the relative prevalence of the main reasons provided. When asked why they wanted to teach, students' explanations were primarily related to: 'liking' or 'loving' children (18\%), the idea of teaching/being a teacher (14\%), and/or a particular subject area (6\%); a desire to help children to learn (16\%); a perception that it would be fun or enjoyable to work as a teacher (12\%); and/or, because they consider themselves skilled or otherwise suitable for teaching $(8 \%)$. In general, altruistic concerns to help children learn and intrinsic motivations based on the attractiveness of teaching as a rewarding job dominated students' explanations for their interest. These findings indicate that despite negative representations of teachers, school students who were interested in teaching expressed overwhelmingly positive views of the job and confidence in their own suitability.

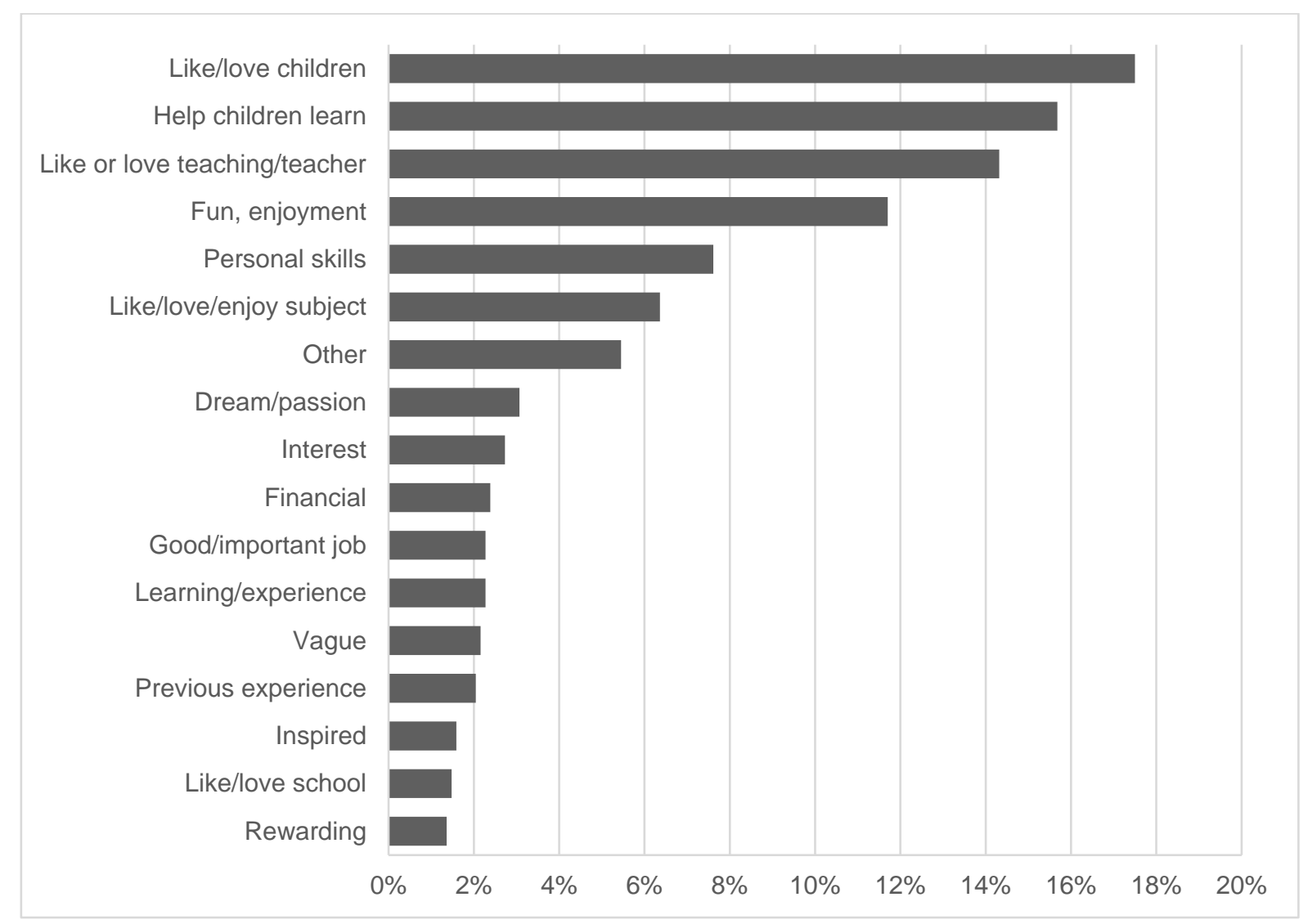

Fig. 3 Reasons for interest in teaching

The main differences among students were: girls more frequently referred to 'liking' and 'loving' children (20\% females; $5 \%$ males); boys more often declared their interest in a particular school subject (14\% males; $5 \%$ females); and, Indigenous students more often named their desire to help children learn (19\% Indigenous; $15 \%$ non-Indigenous) and their affection for a particular teachers (19\% Indigenous; 14\% non-Indigenous) but less often 
declared themselves to have the personal skills that made them well suited to the role $(5 \%$ Indigenous; $8 \%$ non-Indigenous) or to love a particular subject (4\% Indigenous; $7 \%$ nonIndigenous).

Table 3 exemplifies the main themes. These examples reproduce students' words, unedited. For reference, we have indicated the gender, year level, SES background (high, middle, low), and prior achievement level (high, middle, low) for each student response and indicated those students who identified as Indigenous. For space reasons, we have not illustrated the strong sentiment of students that they like or love 'children', 'kids', 'young people', or the idea of working with them. 
Table 3 Examples of students' reasons for interest in teaching

$\begin{array}{ll}\text { Theme } & \text { Examples } \\ \begin{array}{l}\text { Desire to make a } \\ \text { difference/help people }\end{array} & \begin{array}{r}\text { I'd like to help children have a better life. (Female, Year 10, Middle SES, Low } \\ \text { Achievement) } \\ \text { because i want to help other kids learn. I want them to be smart when they grow up } \\ \text { (Female, Year 3, Middle SES, Middle Achievement, Indigenous) } \\ \text { because i want to help kids learn new things and i want to make sure they know } \\ \text { everything they can about this world (Female, Year 5, Middle SES, High } \\ \text { Achievement) } \\ \text { I love helping and teaching people through a calm way of learning, also love } \\ \text { sovling emotional problems (Female, Year 10, Middle SES, Middle } \\ \text { Achievement) } \\ \text { I want to help our younger generations thrive (Male, Year 9, Middle SES, High } \\ \text { Achievement) } \\ \text { I'm inspired by how the teachers can help others (Female, Year 3, High SES, High } \\ \text { Achievement) }\end{array}\end{array}$

Sense of personal suitability

Passion for a particular subject(s)

View of teaching as a rewarding job because $\mathrm{i}$ am pretty smart (in the top class and Gifted and Talented group) and I like school (Female, Year 7, Middle SES, High Achievement)

because i think am really clever and i love kids (Female, Year 6, Middle SES, Middle Achievement)

I would like to be teacher because I am good with maths (Female, Year 3, High SES, High Achievement)

I'm very educated and intelligent (well I like to think so at least) and I love the idea of preparing and teaching work for students. (Female, Year 5, Low SES, High Achievement)

because i'm so good at doing maths so i thought that i might become a teacher (Male, Year 6, Middle SES, Middle Achievement)

I thouroughly enjoy writing descriptive stories for people of my age, and I love working with children. In being a teacher, I could express many of my talents to younger children. (Female, Year 7, High SES, High Achievement)

my passion is enviromental science and $\mathrm{i}$ would like to share my passion with students in fututre generations. (Female, Year 12, Middle SES, Middle Achievement)

I love english because I'm good at spelling and writing (Female, Year 6, Middle Achievement)

I enjoy the subject of pdhpe and have a good understanding of the concepts involved, and it seems to be an excellent job. (Male, Year 11, Low SES, High Achievement)

Because I've always seen History as a important and interesting part of life and education. (Male, Year 10, Middle SES, Middle Achievement)

because I love cemistry and i always wanted to be a Teacher (Male, Year 4, Middle SES, High Achievement)

because I think teaching is rewarding and I like the idea of knowing about something so much that you get to teach it. (Female, Year 12, Low SES)

Because I've always wanted to teach people to do things and the teachers at my school inspire me. (Female, Year 5, Middle SES, Middle Achievement)

to teach is to learn twice (Female, Year 6, Middle SES, High Achievement)

Because $\mathrm{i}$ want to be someone who inspires childeren and give them the insentive to learn. and not be someone who just shows up to get payed (Female, Year 9, High SES, Middle Achievement)

this kind of job would be hard work but very rewarding. (Female, Year 11, Middle SES, Middle Achievement) 


\section{Implications for policy}

Current policies designed to ensure the 'quality' of teachers, and especially those declaring a need for teachers to come from the top $30 \%$ of the population in terms of literacy and numeracy, problematise the academic credentials of current and prospective teachers, constituting them as the problem. Similarly, efforts to attract more of 'the best and the brightest' reinforce a perceived inadequacy among current recruits. Our point is not to take a particular position 'for' or 'against' current policy, nor to suggest we can identify the 'real' 'problem' (Bacchi 2012). Rather, our data provide a counter-narrative about who seeks to teach and selection policies that constitute teachers as the problem.

Most pertinent to the current policy context is our finding that prior achievement, as determined by students' NAPLAN results, was not a statistically significant predictor of interest in teaching. This result calls into question whether current resource-intensive efforts to lift the quality of aspiring teachers are warranted. If a considerable proportion of students interested in teaching come from the top academic quartile (31\%), and the majority of students interested in teaching see themselves as 'above' or 'well-above' average in comparison with their classmates (52\%), and many have a high opinion of their academic capacities and broader suitability as conveyed in the reasons given for interest in teaching, there should be plenty of high achieving applicants to teaching. In this context, policy that locks in academic achievement as the key problem might be misguided. Maintaining interest in teaching among school students may present a greater challenge, particularly if aspirants are bombarded with rhetoric that lowers esteem for teachers and teaching.

Rather than investing so heavily in the regulation of who can teach, Australian education policy makers might consider ways to capitalise on the widespread interest in and enthusiasm for teaching that appears to exist among school students, including high achieving students and including in the later years of high school. While we acknowledge that childhood aspirations might not necessarily translate into occupational outcomes (Furlong and Biggart 1999; Gottfredson 1996; Levine and Zimmerman 1995), the positive dispositions evident in students' articulations of why they were interested in teaching provide a strong basis for a different narrative about prospective teachers - a narrative that might attract rather than deter high achieving applicants. Contrary to the view that aspiring teachers are frequently lacking in capability and suitability, the students in our study did not regard themselves in this way at all. Instead, they believed teaching was something they would be 'good at,' often on the basis of their own strong performance in school and passion for particular subjects and/or working with children. They also named teaching as inspiring and rewarding, a way to help, to make a difference, ensuring the well-being of future generations, and fulfilling an altruistic desire to 'give back'.

These motivations for teaching align closely with those found in previous, related studies. For instance, Richardson and Watt (2006), who surveyed first-year preservice teachers in three Australian universities, found that 'perceived abilities, the intrinsic value of teaching, and the desire to make a social contribution, shape the future, and work with children/adolescents' (p. 44) were the most popular motivations, while conceptions of teaching as a 'back-up plan' were among the least.

In any case, the idea that academic achievement should be a key concern in the selection of teachers which has gained momentum both in Australia (e.g., Bowles et al. 2014; Dinham 2013) and abroad (e.g., Lankford et al. 2015; Epstein and Miller 2011), rests on 
flimsy evidence of a relationship between such achievement and success as a teacher. Although there is clear merit to arguments that teachers with high intellectual capacity which is not synonymous with performance on literacy and numeracy tests - are needed, especially for supporting the learning of students from social groups that have historically been failed by schooling and whose outcomes remain disproportionately lower, other considerations are equally important. For example, some contend that cultural diversity is a paramount concern in the selection of teacher candidates so that the workforce reflects the heterogeneity of cultural backgrounds in society more broadly (e.g., Bireda and Chait 2011; Poloma 2014). Such suggestions are largely absent from current Australian debates on 'teacher selection'. The recent More Aboriginal and Torres Strait Islander Teachers Initiative (MATSITI 2015) is an example of a scheme that treats other factors as at least equally important in securing teachers who can achieve strong outcomes, including academic outcomes, for students across all demographic categories. Our finding that students who identify as Aboriginal or Torres Strait Islander had 1.6 times the odds of expressing interest in teaching as non-Aboriginal students augurs well for achieving such goals. Although our analysis did not explore the intersectionality of the characteristics tested, we note that the gender difference for interest in teaching was greater for Indigenous students than it was for non-Indigenous students, with interest in teaching particularly strong among Indigenous girls.

The continuation of teaching as a gendered occupation, with girls five times more likely to express an interest in teaching, was an unsurprising result given the current gender distribution in undergraduate teacher education programs (see Figure 1) and current workforce data (Centre for Education Statistics and Evaluation 2014; Queensland College of Teachers 2015). This result was even stronger for those aspiring to primary school teaching, in a comparison of the students who specified primary teaching $(n=135,86 \%$ female, $14 \%$ male) with those specifying secondary teaching ( $n=147,52 \%$ female, $48 \%$ male). These differences between aspiring primary and secondary teachers also align closely with current workforce patterns (Queensland College of Teachers 2015).

Despite past efforts to attract more males to primary school teaching, the strength of societal gender relations and discourses about teaching as women's work, especially working with young children (Acker 1983), is likely to account for these patterns. The predominance of liking or loving children as a reason for interest in teaching, especially among the girls in our sample, provides evidence of such discourses at work. This intransigence of gendered interest in teaching, apparent even among the responses of primary school children, illustrates the power of representations in shaping career interests. It also reinforces our concern about the longer term effects of policy discourses that construct teachers as problematic. The more teachers are represented as not good enough, the harder it is likely to be to transform (views of) the profession.

As Graham (2015) puts it, concerns about 'quality teaching' have 'morphed into the odious mantra of "teacher quality"' (n.p.) with the implication that characteristics of 'quality" teachers are simply possessed by an individual or not. Such a position is amplified by recent calls not only to identify applicants' academic aptitude for teaching but also to assess aspects of their non-academic aptitude in relation to levels of motivation, willingness and conscientiousness, interpersonal and communication skills, and personal 'protective' factors such as resilience and self-efficacy at the point of selection into teacher education (Bowles et al. 2014; Sautelle et al. 2015). 
As Burke and McManus (2009) illustrate in their study of the selection procedures of UK tertiary art and design institutions, the notion that particular characteristics can be 'objectively' identified at the point of program entry is one that ought to be subjected to greater scrutiny. They argue that in such processes "judgments are being enacted, which are claimed to be "fair" and "transparent" and even "value-free" but clearly... are embedded in histories of classed and racialised inequalities' (p. 26). Similarly, Southgate and Bennett (2014) take issue with the association of 'capabilities' 'with older discourses about ability, potential and talent as if it were entirely spontaneously-occurring, natural and innate to individuals' (p. 30). Both argue that such processes obscure deeply embedded and embodied inequalities.

The reasoning underpinning current policies to regulate who teaches is circular: an increase in the status of teaching is needed to attract high achievers; more high achievers will raise the status of the profession. Yet current policies which effectively denounce the quality of current teachers and student teachers might not only deter potentially great teachers who are doubtful about making this (top 30\%) grade, they might even deter the very high achievers that the policies are designed to attract. As Bullough and Hall-Kenyon (2011) caution in the context of increasing regulation of teaching and teacher education in the US, 'what sort of people will be attracted to teaching, knowing that they may find themselves working under ever-tightening administrative controls?' (pp. 127-128). Our findings present a counter-narrative to the portrayal of teachers and teacher candidates as unsuitable for the job. As one of the only studies, internationally, of school students' interest in teaching, this alternative representation of who wants to teach suggests a more hopeful future of teaching being in good hands.

\section{References}

Acker, S. (1983). Women and teaching: A semi-detached sociology of a semi-profession. In S. Walker \& L. Barton (Eds), Gender, class and education. Sussex, UK: Falmer Press.

Allard, A., Mayer, D., \& Moss, J. (2014). Authentically assessing graduate teaching: Outside and beyond neo-liberal constructs. Australian Educational Researcher, 41(4), 425443. doi:10.1007/s13384-013-0140-x

Auguste, B., Kihn, P., \& Miller, M. (2010). Closing the talent gap: Attracting and retaining top-third graduates to careers in teaching. New York, NY: McKinsey.

Australian Government Department of Education and Training. (2015). Teacher quality. Retrieved April 30, 2016 from https://www.studentsfirst.gov.au/teacher-quality

Australian Government Department of Education and Training. (2016). uCube. Retrieved April 30, 2016 from http://highereducationstatistics.education.gov.au

Australian Institute for Teaching and School Leadership. (AITSL). (2011). Accreditation of initial teacher education programs in Australia: Standards and procedures. Melbourne, Australia: Ministerial Council for Education, Early Childhood Development and Youth Affairs. 
Australian Institute for Teaching and School Leadership. (AITSL). (2012). Accreditation of initial teacher education programs in Australia: Guide to the accreditation process. Melbourne, Australia: Ministerial Council for Education, Early Childhood Development and Youth Affairs.

Australian Institute for Teaching and School Leadership. (AITSL). (2015). Accreditation of initial teacher education programs in Australia: Standards and procedures. Melbourne, Australia: AITSL.

Bacchi, C. (2012). Why study problematizations? Making politics visible. Open Journal of Political Science, 2(1), 1-8.

Bagshaw, E. (2016, 22 January). Teaching students to face personality assessments. The Sydney Morning Herald. Retrieved January 30, 2016 from http://www.smh.com.au/national/education/teaching-students-to-face-personalityassessments-20160118-gm8qse.html

Barber, M., \& Mourshed, M. (2007). How the world's best-performing schools come out on top. Retrieved October 13, 2015 from http://mckinseyonsociety.com/downloads/reports/Education/Worlds_School_Systems _Final.pdf

Bireda, S., \& Chait, R. (2011). Increasing teacher diversity: strategies to improve the teacher workforce. Washington, DC: Center for American Progress.

Bourdieu, P. (1986). The forms of capital. In J. E. Richardson (Ed.), Handbook of theory and research for the sociology of education (pp. 241-258). New York, NY: Greenwood Press.

Bowles, T., Hattie, J., Dinham, S., Scull, J., \& Clinton, J. (2014). Proposing a comprehensive model for identifying teaching candidates. The Australian Educational Researcher, 41(4), 365-380.

Bradley, D., Noonan, P., Nugent, H., \& Scales, B. (2008). Review of Australian higher education: Final report. Canberra, Australia: Commonwealth of Australia.

Bullough, R. V., \& Hall-Kenyon, K. M. (2011). The call to teach and teacher hopefulness. Teacher Development: An International Journal of Teachers' Professional Development, 15(2), 127-140.

Burke, P. J., \& McManus, J. (2009). Art for a few: Exclusion and misrecognition in art and design higher education admissions. London, UK: National Arts Learning Network.

Byrne, E. (2013, 24 July). Entry standards for teachers are too low. The Age. Retrieved October 13, 2015 from http://www.theage.com.au/comment/entry-standards-forteachers-are-too-low-20130723-2qhf5.html

Centre for Education Statistics and Evaluation. (2014). Workforce profile of the NSW teaching profession 2014. Retrieved October 13, 2015 from http://www.cese.nsw.gov.au/images/stories/PDF/Workforce_Profile_NSW_Teaching _Profession_2014.pdf 
Commonwealth Department of Education. (2014). 2013 National Early Childhood Education and Care workforce census (Report). Melbourne, Australia: The Social Research Centre. Retrieved from https://docs.education.gov.au/system/files/doc/other/nwc_national_report_final_0.pdf

Cross, M., \& Ndofirepi, E. (2015). On becoming and remaining a teacher: Rethinking strategies for developing teacher professional identity in South Africa. Research Papers in Education, 30(1), 95-113. doi:10.1080/02671522.2013.851729

Devlin, M. (2016, 11 April). ATAR is a university marketing tool: 4 reasons to stop obsessing about it, EduResearch Matters. Retrieved April 20, 2016 from http://www.aare.edu.au/blog/?p=1511

Dinham, S. (2008). How to get your school moving and improving: an evidence-based approach. Camberwell, Australia: ACER Press.

Dinham, S. (2013). The quality teaching movement in Australia encounters difficult terrain: A personal perspective. Australian Journal of Education, 57(2), 91-106.

Dinham, S., Ingvarson, L., \& Kleinhenz, E. (2008). Teaching talent: The best teachers for Australia's classrooms. Melbourne, Australia: The Business Council of Australia.

Epstein, D., \& Miller, R. T. (2011). Slow off the mark: Elementary school teachers and the crisis in science, technology, engineering, and math education. Washington, DC: Center for American Progress.

Ferrari, J. (2015, 20 February). Smart choice: Top kids make the best teachers. The Australian. Retrieved October 13, 2015 from http://www.theaustralian.com.au/national-affairs/education/smart-choice-top-kidsmake-the-best-teachers/story-fn59nlz9-1227226255449

Flores, M. A., \& Niklasson, L. (2014). Why do student teachers enrol for a teaching degree? A study of teacher recruitment in Portugal and Sweden. Journal of Education for Teaching, 40(4), 328-343. doi:10.1080/02607476.2014.929883

Furlong, A., \& Biggart, A. (1999). Framing 'choices': A longitudinal study of occupational aspirations among 13- to 16-year-olds. Journal of Education and Work, 12(1), 21-35. doi:10.1080/1363908990120102

Goldstein, H. (2011a). Multilevel statistical models. Chichester, UK: John Wiley \& Sons.

Goldstein, R. A. (2011b). Imaging the frame: Media representations of teachers, their unions, NCLB, and education reform. Educational Policy, 25(4), 543-576.

Gore, J., Holmes, K., Smith, M., Southgate, E., \& Albright, J. (2015). Socioeconomic status and the career aspirations of Australian school students: Testing enduring assumptions. Australian Educational Researcher, 42(2), 155-177.

Gore, J., Holmes, K., Smith, M., Fray, L., McElduff, P., Weaver, N., \& Wallington, C. (2016). Unpacking the career aspirations of Australian school students: Towards an 
evidence base for university equity initiatives in schools. Manuscript submitted for publication.

Gottfredson, L. S. (1996). Gottfredson's theory of circumscription and compromise. In D. Brown \& L. Brooks (Eds.), Career choice and development: Applying contemporary approaches to practice (3rd ed., pp. 179-232). San Francisco, CA: Jossey-Bass.

Graham, L. (2015, 29 March). Lay off blaming new teachers for 'falling' standards. EduResearch Matters. Retrieved October 13, 2015 from http://www.aare.edu.au/blog/?p=964

Hobson, A. J., Ashby, P., McIntyre, J., \& Malderez, A. (2010). International approaches to teacher selection and recruitment (OECD Education Working Paper No. 47). doi:10.1787/5kmbphhh6qmx-en

Ingvarson, L., Reid, K., Buckley, S., Kleinhenz, E., \& Masters, G. N. (2014). Best practice teacher education programs and Australia's own programs. Canberra, Australia: Department of Education.

James, R., Bexley, E., Anderson, A., Devlin, M., Garnett, R., Marginson, S., \& Maxwell, L. (2008). Participation and equity: A review of the participation in higher education of people from low socioeconomic backgrounds and Indigenous people (Report). Melbourne, Australia: Centre for the Study of Higher Education. Retrieved October 7, 2016 from

https://www.universitiesaustralia.edu.au/ArticleDocuments/210/Participation\%20and $\% 20$ equity.pdf.aspx

Lai, K. C., Chan, K. W., Ko, K. W., \& So, K. S. (2005). Teaching as a career: A perspective from Hong Kong senior secondary students. Journal of Education for Teaching, 31(3), 153-168. doi:10.1080/02607470500168974

Lankford, H., Loeb, S., McEachin, A., Miller, L. C., \& Wyckoff, J. (2014). Who enters teaching? Encouraging evidence that the status of teaching is improving. Educational Researcher, 43(9), 444-453.

Levine, P. B., \& Zimmerman, D. J. (1995). A comparison of the sex-type of occupational aspirations and subsequent achievement. Work and Occupations, 22(3), 73-84.

Louden, W. (2008). 101 damnations: The persistence of criticism and the absence of evidence about teacher education in Australia. Teachers and Teaching: Theory and Practice, 14(4), 357-368.

Lovett, S. (2007). 'Teachers of promise': Is teaching their first career choice. New Zealand Annual Review of Education, 16, 29-53. Retrieved October 13, 2015 from http://hdl.handle.net/10092/1691

Manuel, J., \& Hughes, J. (2006). 'It has always been my dream': Exploring pre-service teachers' motivations for choosing to teach. Teacher Development, 10(1), 5-24. doi:10.1080/13664530600587311 
McDougall, B. (2014, 18 December). Principals demand radical overhaul of student teacher selection to improve academic outcomes. The Daily Telegraph. Retrieved October 13, 2016 from http://www.dailytelegraph.com.au/news/nsw/principals-demand-radicaloverhaul-of-student-teacher-selection-to-improve-academic-outcomes/story-fni0cx 121227160381062

McNeilage, A. (2014, 21 January). Adrian Piccoli says teacher selection criteria should be more strict. The Sydney Morning Herald. Retrieved January 22, 2014 from http://www.smh.com.au/national/education/adrian-piccoli-says-teacher-selectioncriteria-should-be-more-strict-20140120-314vn.html

More Aboriginal and Torres Strait Islander Teachers Initiative. (MATSITI). (2015). About MATSITI. Retrieved March 10, 2016 from http://matsiti.edu.au/about/

Moulton, V., Flouri, E., Joshi, H., \& Sullivan, A. (2015). Fantasy, unrealistic and uncertain aspirations and children's emotional and behavioural adjustment in primary school. Longitudinal and Life Course Studies, 6(1), 107-119. doi:10.14301/llcs.v6i1.277

NSW Board of Studies Teaching and Educational Standards. (NSW BOSTES). (2015a). Raising university entry standards for future teachers. Retrieved March 10, 2016 from http://nswteachers.nsw.edu.au/future-returning-teachers/become-ateacher/raising-university-entry-standards/

NSW Board of Studies Teaching and Educational Standards. (NSW BOSTES). (2015b). Understanding HSC results. Retrieved March 10, 2016 from http://www.boardofstudies.nsw.edu.au/hsc-results/understanding.html

Poloma, A. W. (2014). Why teaching faculty diversity (still) matters. Peabody Journal of Education, 89(3), 336-346.

Pyne, C. (2014, 18 February). A quality education begins with the best teachers, says Christopher Pyne. The Sydney Morning Herald. Retrieved February 18, 2014 from http://www.smh.com.au/federal-politics/political-opinion/a-quality-education-beginswith-the-best-teachers-says-christopher-pyne-20140218-32z61.html

Queensland College of Teachers. (2015). Teacher profile: 2013 Queensland graduate teachers. Retrieved March 10, 2016 from https://www.qct.edu.au/PDF/Research/Teacher\%20Profile\%202013\%20QLD\%20Gra d.PDF

Richardson, P. W., \& Watt, H. M. G. (2006). Who chooses teaching and why? Profiling characteristics and motivations across three Australian universities. Asia-Pacific Journal of Teacher Education, 34(1), 27-54.

Sahlberg, P. (2007). Education policies for raising student learning: The Finnish approach. Journal of Education Policy, 22(2), 147-171.

Sautelle, E., Bowles, T., Hattie, J., \& Arifin, D. N. (2015). Personality, resilience, selfregulation and cognitive ability relevant to teacher selection. Australian Journal of Teacher Education, 40(4), 54-71. doi:10.14221/ajte.2015v40n4.4 
Southgate, E., \& Bennett, A. (2014). Excavating widening participation policy in Australian higher education: Subject positions, representational effects, emotion. Creative Approaches to Research, 7(1), 21-45.

Southgate, E., Douglas, H., Scevak, J., Macqueen, S., Rubin, M., \& Lindell, C. (2014). The academic outcomes of first-in-family in an Australian university: An exploratory study. International Studies in Widening Participation, 1(2), 31-45.

Teacher Education Ministerial Advisory Group. (TEMAG). (2014). Action now: Classroom ready teachers. Canberra, Australia: Department of Education and Training. Retrieved October 13, 2015 from https://docs.education.gov.au/system/files/doc/other/action_now_classroom_ready_te achers_print.pdf

Trounson, A. (2016, 2 March). Finding a way through the policy maze. Pursuit. Retrieved March 10, 2016 from https://pursuit.unimelb.edu.au/articles/finding-a-way-throughthe-policy-maze

Ulmer, J. B. (2016). Re-framing teacher evaluation discourse in the media: An analysis and narrative-based proposal. Discourse: Studies in the Cultural Politics of Education, 37(1), 43-55. doi:10.1080/01596306.2014.921756

University of New England. (UNE). (n.d.). Response to AITSL's 2010 national system for the accreditation of preservice teacher education programs: proposal for consultation. Retrieved March 22, 2016 from http://www.aitsl.edu.au/docs/default-source/defaultdocument-library/university_of_new_england

Ure, C. (2015, 15 October). Why scrap teaching degrees? There is no crisis in teacher education. The Conversation. Retrieved March 10, 2016 from http://theconversation.com/why-scrap-teaching-degrees-there-is-no-crisis-in-teachereducation-49059

Weldon, P. R. (2015). The teacher workforce in Australia: Supply, demand and data issues. Policy Insights, Issue 2. Melbourne, Australia: Australian Council for Educational Research.

Wilson, R., Dalton, B., \& Baumann, C. (2015, 16 March). Six ways Australia's education system is failing our kids. The Conversation. Retrieved March 18, 2015 from https://theconversation.com/six-ways-australias-education-system-is-failing-our-kids32958

Yüce, K., Şahin, E., Koçer, Ö., \& Kana, F. (2013). Motivations for choosing teaching as a career: A perspective of pre-service teachers from a Turkish context. Asia Pacific Education Review, 14(3), 295-306. doi:10.1007/s12564-013-9258-9

Zhang, H., Yu, Q., Feng, C., Gunzler, D., Wu, P., \& Tu, X. M. (2012). A new look at the difference between the GEE and the GLMM when modeling longitudinal count responses. Journal of Applied Statistics, 39(9), 2067-2079. 